American Journal of Biochemistry and Biotechnology 5 (1): 14-20, 2009

ISSN 1553-3468

(C) 2009 Science Publications

\title{
Uptake and Recovery of Lead by Agarose Gel Polymers
}

\author{
${ }^{1}$ Anurag Pandey, ${ }^{2}$ Anupam Shukla and ${ }^{3}$ Lalitagauri Ray \\ ${ }^{1}$ School of Biotechnology, Rajiv Gandhi Technological University, \\ Bhopal- 462036 India \\ ${ }^{2}$ Atal Bihari Vajpayee-Indian Institute of Information Technology and Management, \\ Gwalior-474 010 India \\ ${ }^{3}$ Department of Food Technology and Biochemical Engineering, \\ Jadavpur University, Kolkata-700 032 India
}

\begin{abstract}
Problem statement: The uptake and recovery of lead ions were investigated by using agarose gel polymers. Approach: The experimental results showed that the agarose gel were effective in removing $\mathrm{Pb}$ (II) from solution. Biosorption equilibrium was approached within $4 \mathrm{~h}$. Pseudo secondorder was applicable to all the sorption data over the entire time range. Results: The sorption data conformed well to both the Langmuir and the Freundlich isotherm model. The maximum adsorption capacity $\left(\mathrm{q}_{\max }\right)$ onto agarose gel was $115 \mathrm{mg} \mathrm{g}^{-1}$ for $\mathrm{Pb}$ (II). The maximum uptake of metal ions was obtained at $\mathrm{pH} 2.0$. At temperature $35^{\circ} \mathrm{C}$, the biosorption of metal ions was found to be highest, with increase or decrease in temperature resulted in a decrease in the metal ions uptake capacity. Conclusion: Elution experiments were carried out to remove $\mathrm{Pb}$ (II) ions from loaded agarose gel and the bound metal ions could be eluted successfully using 0.1 M EDTA solution. The results suggest that agarose gel can be used as a biosorbent for an efficient removal of $\mathrm{Pb}$ (II) ions from aqueous solution.
\end{abstract}

Key words: Uptake, recovery, biosorption, lead, agarose gel

\section{INTRODUCTION}

The removal of toxic or economically important heavy metal ions from wastewaters is of great importance from an environmental and industrial viewpoint. The ubiquity of heavy metals in the biosphere results in the introduction of high amounts of toxic metals into the food chain from various sources. Heavy metals released into the environment by technological activities tend to persist indefinitely, circulating and eventually accumulating throughout the food chain, becoming a serious threat to the environment ${ }^{[1]}$.

Among the earliest of metals to be discovered and used, lead has played a prominent role in human activity. Human exposure to lead is common and results from the many uses of this metal due to its exceptional properties. The largest industrial use of lead today is for the production of lead batteries, largely used in the automobile industry. Lead is not biodegradable, it never disappears, only accumulates where it is deposited. Lead provides no known biological benefit to human. Lead is associated with a continuum of health effects at both high levels of exposure resulting in damage to virtually all organs and organ systems, culminating ultimately in death at excessive levels of exposure to effects at low levels, including effects on heam synthesis and other biochemical processes, impairment of psychological and neurobehavioral functions and a range of other effects ${ }^{[2]}$.

A variety of methods are used to remove toxic heavy metals from effluents and industrial wastewaters before discharging into a natural water bodies. Conventional metal removal procedures such as solvent extraction, chemical precipitation, reverse osmosis, ion exchange, lime coagulation, evaporation and electrolysis are encountered with certain major disadvantages such as incomplete removal, high reagent and energy requirements, generation of toxic sludge or other waste products, which necessitates careful disposal in further steps ${ }^{[3,4]}$. Most of the heavy metal salts are soluble in water and form aqueous solutions and consequently cannot be separated by ordinary physical means of separation. The application of membrane processes and activated carbon are also restricted due to high costs. As a result, cost effective

Correspondence Author: Anurag Pandey, School of Biotechnology, Rajiv Gandhi Technological University,

Bhopal- 462036 India 
alternative technologies involving removal of heavy metals from wastewater are being sought to meet discharge standards.

The search for alternative and innovative treatment techniques has focused attention on the use of biological materials for the removal and recovery technologies and has gained importance during recent years because of better performance and low cost of these biological materials. The Biological methods of metal removal, defined as bio sorption, have been recommended as cheaper and more effective techniques. In bio sorption, either live or dead microorganisms or their derivatives are used, which complex metal ions through the functioning of legends or functional groups located on the outer surface of the sorbent ${ }^{[5]}$. Bio sorption of heavy metals is one of the most promising technologies involved in removal of toxic metals from industrial waste streams and natural waters $^{[6]}$ It is based on the ability of biological materials to accumulate heavy metals from wastewater by either metabolically mediated or physico-chemical pathways of uptake ${ }^{[7]}$.

Bio sorption technology based on the utilization of dead biomass or biopolymers offers certain major advantages such as lack of toxicity constraints, nonrequirements of nutrients supply and recovery of bound metal species by an appropriate desorption method ${ }^{[8]}$. Biopolymers are non-toxic, selective, efficient and inexpensive and thus highly competitive with ion exchange resins and activated carbon ${ }^{[4]}$. The nonviable biomass or biopolymers can be easily stored and used, eliminating the problem of toxicity from heavy metals. Health hazard, when utilizing potentially pathogenic strains, is also eliminated. In addition, it does not require the addition of nutrient for cell growth and the starting-up when they are used in process, resulting in simple process start-up and control. Furthermore, it can be easily regenerated and reused and in some cases provide higher capacity. Metal bound to the cell wall is more easily recovered by elution compared with metals accumulated internally within living cells. Because of these advantages, biopolymers is favored when considered as a potential biosorbent to concentrate and recover heavy metals ${ }^{[9,0,11]}$.

The choice of biopolymer is a key factor in biosorption, which determines the mechanical strength and chemical resistance of the final biosorbent particle, which is to be utilized for sorption-desorption process $^{[9]}$. The aim of this study was to investigate the $\mathrm{Pb}$ (II) biosorption profile of agarose gel and to indicate factors that impact the sorption and elution characteristics of the gels. Laboratory batch experiments were performed with agarose gel to determine optimal $\mathrm{pH}$, temperature required for metal ions binding to the biopolymer, effect of varying adsorbent loadings, initial metal ion concentration, stability of the adsorbent to desorbing reagents and the desorption efficiency in various elutants were compared.

\section{MATERIALS AND METHODS}

Preparation of agarose gel: A desired amount of agarose gel was prepared by dissolving agarose in distilled water and keeping in a boiling water bath and then plated into Petri-plates. The resultant polymerized gel was cut into pieces of approximately $3 \times 3 \mathrm{~mm}^{2}$ sizes.

Metal solutions: Metal stock solutions containing $\mathrm{Pb}$ (II) with a concentration of $1000 \mathrm{mg} \mathrm{L}^{-1}$ were prepared using deionized distilled water and salts containing the metals. For biosorption experiments, concentrations ranging from $25-200 \mathrm{mg} \mathrm{L}^{-1}$ were prepared and $\mathrm{pH}$ of the metal solutions was adjusted to desired value using $0.1 \mathrm{M}$ citrate buffer. For the desorption studies 0.1 M EDTA, 0.1 N NaOH and 0.1 $\mathrm{N} \mathrm{H}_{2} \mathrm{SO}_{4}$ solutions (analytical grade) were used.

Apparatus and glassware: All metal uptake experiments were carried out using $250 \mathrm{ml}$ Erlenmeyer flasks. Metal ion concentrations were determined using Varian spectra A-220 atomic absorption spectrophotometer.

Biosorption studies: Biosorption experiments were carried out in $250 \mathrm{~mL}$ Erlenmeyer flasks by agitating pre-weighed amount of adsorbent with $50 \mathrm{~mL}$ of aqueous metal ion solution, in order to find out the optimum adsorbent loading, for a pre determined time interval at $150 \mathrm{rpm}$ speed using a rotary shaker. The effect of $\mathrm{pH}$ of the suspending medium on metal removal was studied by performing equilibrium sorption tests at different $\mathrm{pH}$ values ranging from $\mathrm{pH}$ 2.0 and 4.0. In order to determine the effect of temperature variation on metal ion uptake by agarose gel, the temperature of the reaction was varied from $20-40^{\circ} \mathrm{C}$. After adsorption, the mixture was filtered through Whatman No. 1 filter paper. Residual concentration of metal ion present in the clear supernatant was estimated. The amount of metal bound was taken to be the difference between the initial and final metal concentration. For isotherm analysis, 
adsorption experiments were conducted by varying the initial metal ion concentration from $25-200 \mathrm{mg} \mathrm{L}^{-1}$ and equilibrated for $4 \mathrm{~h}^{-1}$.

Desorption studies: Agarose gel was subjected to metal ion recovery experiments using $0.1 \mathrm{M}$ EDTA, 0.1 $\mathrm{N} \mathrm{NaOH}$ and $0.1 \mathrm{~N} \mathrm{H}_{2} \mathrm{SO}_{4}$ solutions. After $4 \mathrm{hr}$ of adsorption, the bound metal ions were eluted into $20 \mathrm{ml}$ of each of the elutant for $60 \mathrm{~min}$. After elution, the mixture was filtered and filtrate was measured for metal ion concentration. Desorption efficiency was calculated from the amount of metal ions adsorbed on the biosorbent and the final metal ion concentration in the adsorption medium.

After elution, agarose gel was washed with deionized water, gels regenerated were air dried and then again suspended in metal-containing solutions for the next adsorption run. Three cycles of adsorption/desorption experiments were conducted to examine the capability of the agarose gel to retain metal removal capability.

\section{RESULTS AND DISCUSSION}

Kinetic study of $\mathrm{Pb}$ (II) binding to the agarose gel: Sorption kinetics are important physicochemical parameters to evaluate the basic qualities of a good sorbet. Pseudo second-order equation was employed to model the sorption data over the entire time range. The pseudo second-order kinetic rate equation of Lagergren is generally expressed as follows ${ }^{[13]}$ :

$$
\mathrm{dq} / \mathrm{dt}=\mathrm{k}_{2}\left(\mathrm{q}_{\mathrm{e}}-\mathrm{q}\right)^{2}
$$

where $\mathrm{k}_{2}$ is the pseudo second order rate constant $\left(\mathrm{g} \mathrm{mg} \mathrm{min}^{-1}\right)$. Integrating and applying boundary conditions as $\mathrm{t}=0$ and $\mathrm{q}=0$ to $\mathrm{t}=\mathrm{t}$ and $\mathrm{q}=\mathrm{q}_{\mathrm{e}}$, Eq. (1) becomes:

$$
\mathrm{t} / \mathrm{q}=1 / \mathrm{q}_{\mathrm{e}}{ }^{2} \mathrm{k}_{2}+\mathrm{t} / \mathrm{q}_{\mathrm{e}}
$$

The rate constant $k_{2}$ can be obtained from the intercept of the linearized pseudo second-order rate equation. If the pseudo second-order rate equation can fit the sorption data, there should be good linearity between $\mathrm{t} / \mathrm{q}_{\mathrm{t}}$ and $\mathrm{t}$.

Figure 1 shows that the pseudo second-order equation was applicable to all the sorption data $\left(R^{2}=\right.$ 0.9995), straight line obtained indicating that the process follows pseudo second-order kinetics and $\mathrm{k}_{2}$ value is 4.1. This confirms that there is more than one mechanism involved in the adsorption process.

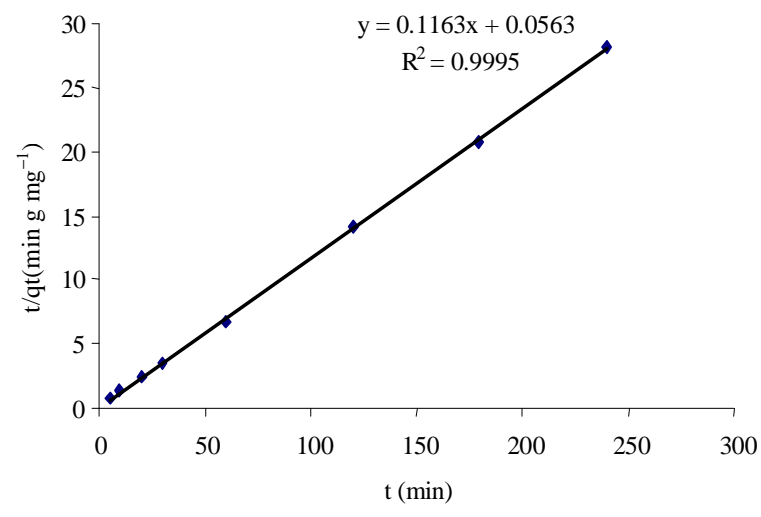

Fig. 1: Plot of $\mathrm{t} / \mathrm{q}_{\mathrm{t}}$ and $\mathrm{t}$

Table 1: Biosorption capacity of agarose gel for $\mathrm{Pb}(\mathrm{II})$ at varying sorbent dose; $50 \mathrm{~mL}$ metal solution $\left(50 \mathrm{mg} \mathrm{L}^{-1}\right)$ of $\mathrm{Pb}$ (II) was contacted with 1-3\% w/v of agarose for $4 \mathrm{~h}$ at $\mathrm{pH} 2.0$ and temperature $35^{\circ} \mathrm{C}$

\begin{tabular}{ll}
\hline Agarose dose $\%(\mathrm{w} / \mathrm{v})$ & Percentage removal of $\mathrm{Pb}(\mathrm{II})$ ions \\
\hline 1 & 58.0 \\
2 & 58.0 \\
3 & 60.0 \\
\hline
\end{tabular}

Effect of agarose concentration on biosorption: In order to optimize the agarose loadings in gel were prepared with varying quantities with $1-3 \%$ (w/v) biopolymer loading. The temperature and $\mathrm{pH}$ of the reaction was fixed at $35^{\circ} \mathrm{C}$ and 2.0 , the initial $\mathrm{Pb}$ (II) concentration was $50 \mathrm{mg} \mathrm{L}^{-1}$ respectively. Experiment was carried out using $50 \mathrm{ml}$ solution in $250 \mathrm{~mL}$ Erlenmeyer flask. The results of biosorption experiments obtained by using gels with varying agarose load are listed in show Table 1. It was observed that $1 \%$ agarose concentration, was found to be optimum for $\mathrm{Pb}$ (II) removal. This can be attributed to the difference in porosity of the gels when a higher quantity of sorbent was loaded. The increase in dose of sorbent in relation to amount reduced the surface area of the gels ${ }^{[14]}$. As the sorbent dose was increased, the gels became less porous and the free transport of metal ions to the interior adsorption sites was affected. Because of the reduced porous nature, the total surface area of entrapped biosorbent particle, interacting with metal ions is reduced.

Effect of pH on biosorption: To study if the biosorption of agarose gel depends on solution $\mathrm{pH}$, metal uptake was studied at $\mathrm{pH}$ ranging from 1.0-4.0. Adjustments to $\mathrm{pH}$ were made with $0.1 \mathrm{M}$ citrate buffer. Metal uptake was affected by $\mathrm{pH}$ of the metal solution (Fig. 2). It is clear that maximum adsorption of $\mathrm{Pb}$ (II) 
Am. J. Biochem. \& Biotech., 5 (1): 14-20, 2009

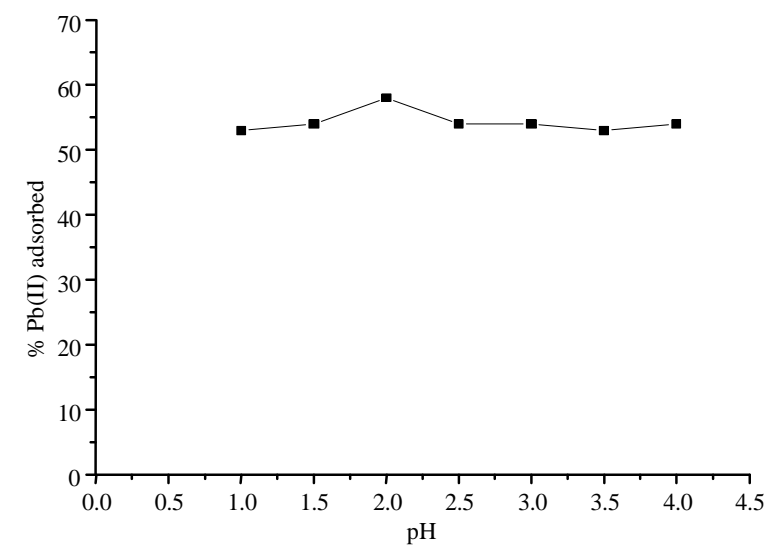

Fig. 2: Effect of $\mathrm{pH}$ on metal uptake by agarose gel, 50 $\mathrm{mL}$ metal solution $\left(50 \mathrm{mg} \mathrm{L}^{-1}\right)$ of $\mathrm{Pb}$ (II) was contacted with $1 \%$ of agarose for $4 \mathrm{~h}$, temperature $35^{\circ} \mathrm{C}$

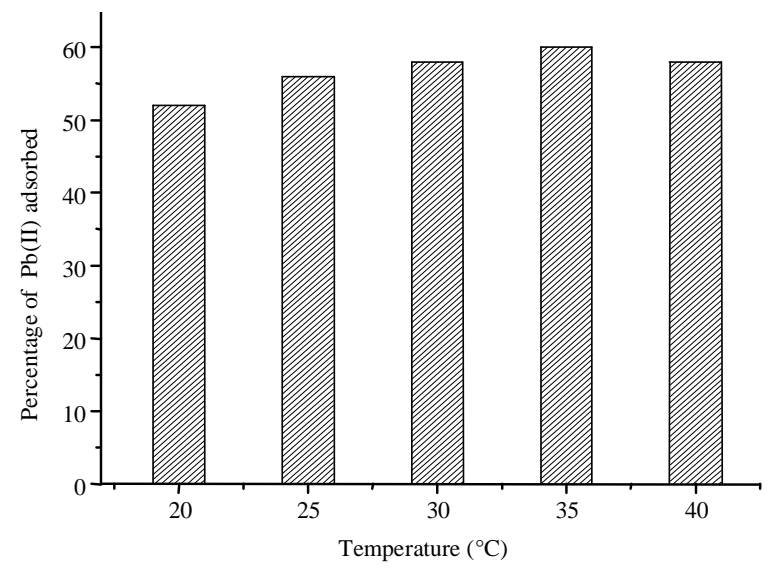

Fig. 3: Effect of temperature on metal biosorption of $\mathrm{Pb}$ (II) by agarose gel, $50 \mathrm{~mL}$ metal solution $\left(50 \mathrm{mg} \mathrm{L}^{-1}\right)$ of $\mathrm{Pb}$ (II) was contacted with $1 \%$ of agarose gel for $4 \mathrm{~h}$ at $\mathrm{pH} 2$

occurred at $\mathrm{pH} 2$ and decreased at lower and higher $\mathrm{pH}$. Metal uptake by agarose gel decreases as the $\mathrm{pH}$ increases and the maximum removal for $\mathrm{Pb}$ (II) ions was $58 \%$ at $\mathrm{pH} 2.0$. This could be due to the $\mathrm{pH}$ of the solution, which may affect the surface charge of the adsorbent.

Effect of temperature on biosorption: Results of metal sorption experiments carried out at different temperature ranging from $20-40^{\circ} \mathrm{C}$ are shown in Fig. 3 . Further, it was observed that the extent of sorption of metal ions by the sorbent increased with increase in

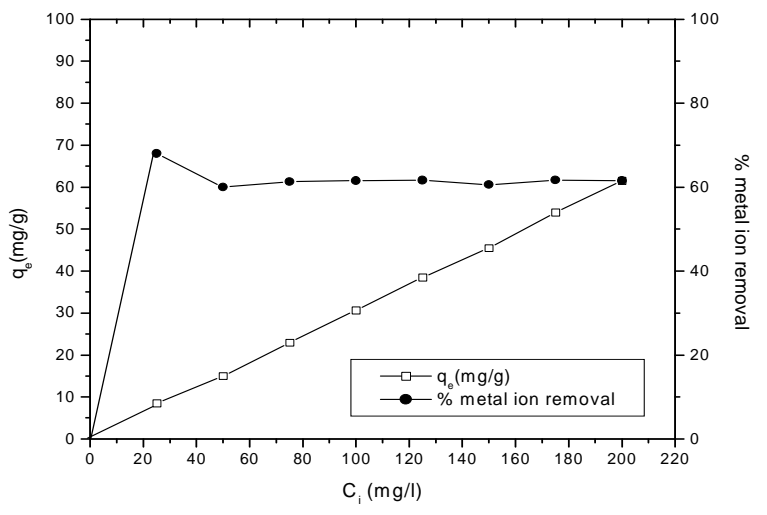

Fig. 4: Effect of initial metal ion concentration on biosorption of $\mathrm{Pb}$ (II) by agarose gel, $50 \mathrm{~mL}$ metal solution (25-200 $\mathrm{mg} \mathrm{L}^{-1}$ ) of $\mathrm{Pb}$ (II) was contacted with $1 \%$ of agarose gel $\mathrm{Pb}$ (II) for $4 \mathrm{~h}$ at $\mathrm{pH} 2$ and temperature $35^{\circ} \mathrm{C}$

temperature upto $35^{\circ} \mathrm{C}$. Further increase in the temperature of the reaction mixture showed reduction in biosorption. The figure shows that maximum sorption was observed at temperature $35^{\circ} \mathrm{C}$. It has been suggested that increase in metal uptake at increased temperature is due to either higher affinity of sites for metal or an increase in binding sites on relevant biosorbent ${ }^{[3,8]}$.

Effect of initial metal ion concentration on biosorption: Heavy metal ion biosorption capacities of agarose gel are presented as a function of the initial concentration of $\mathrm{Pb}$ (II) ions within aqueous solution in Fig. 4. The removal efficiency was found to be higher at lower initial concentration; the reduction in adsorption was observed when concentration increased from $25-200 \mathrm{mg} \mathrm{L}^{-1}$. This could be because at higher concentrations, as more ions are competing for the available binding sites, the rate of adsorption decreased, resulting in lower adsorption percentage.

Isotherms biosorption analysis: Analysis of equilibrium data is essential to develop an equation which precisely represents the results and which can be used for design purposes. Various isotherm models have been used for the equilibrium modelling of biosorption systems. The most widely used isotherm models to describe the biosorption process are Langmuir and Freundlich model.

The Langmuir isotherm assumes monolayer adsorption and is presented by the following equation: 
Am. J. Biochem. \& Biotech., 5 (1): 14-20, 2009

$$
\mathrm{q}_{\mathrm{e}}=\mathrm{q}_{\max } \mathrm{bC}_{\mathrm{eq}}\left(1+\mathrm{bC}_{\mathrm{eq}}\right)^{-1}
$$

Where $\mathrm{q}_{\mathrm{e}}$ and $\mathrm{q}_{\max }$ are the observed uptake capacity at equilibrium and maximum uptake capacities $\left(\mathrm{mg} \mathrm{g}^{-1}\right.$ biosorbent), $\mathrm{C}_{\mathrm{eq}}$ is the equilibrium concentration ( $\mathrm{mg}$ $\mathrm{L}^{-1}$ solution); $\mathrm{b}$ is the equilibrium constant $\left(\mathrm{L} \mathrm{mg}^{-1}\right)$.

The linearized form of this equation is as:

$$
1 \mathrm{q}^{-1}=1 \mathrm{q}_{\mathrm{m}} \mathrm{b}^{-1} \cdot 1 \mathrm{C}_{\mathrm{e}}^{-1}+1 \mathrm{q}_{\mathrm{m}}^{-1}
$$

$1 / \mathrm{q}_{\mathrm{e}}$ vs $1 / \mathrm{C}_{\mathrm{e}}$ gives the straight line with slope $1 / \mathrm{q}_{\mathrm{m}} \mathrm{b}$ and $1 / \mathrm{q}_{\mathrm{m}}$ as intercept. $\mathrm{b}$ is the sorption isotherm constant ( $\mathrm{L} / \mathrm{mg})$.

The Freundlich isotherm equation is an empirical equation based on the sorption on a heterogeneous surface suggesting that binding sites are not equivalent and /or independent. The monocomponent Freundlich isotherm equation ${ }^{[5]}$ is given below:

$$
\mathrm{q}_{\mathrm{e}}=\mathrm{K}_{\mathrm{f}} \mathrm{C}_{\mathrm{e}}^{1 / \mathrm{n}}
$$

where $\mathrm{K}_{\mathrm{f}}$ is the Fruendlich isotherm constant, related to sorption capacity; $\mathrm{n}$ is the constant related to affinity of the metal ions on adsorbent.

A logarithmic plot linearized the equation

$$
\ln q_{e}=\ln K_{f}+1 n^{-1} \ln C_{e}
$$

Where, $\mathrm{q}_{\mathrm{e}}$ the amount of metal ions adsorbed per unit mass of adsorbent at equilibrium, mg/g, $\mathrm{C}_{\mathrm{e}}$ equilibrium concentration of aqueous solution, $\mathrm{mg} / \mathrm{l}, \mathrm{K}_{\mathrm{f}}$ constant related to adsorption capacity, $1 / \mathrm{n}$ constant related to adsorption intensity.

$\operatorname{lnq}_{\mathrm{e}}$ vs $\operatorname{lnC}_{\mathrm{e}}$ gives the straight line with slope $1 / \mathrm{n}$ and $\ln \mathrm{K}_{\mathrm{f}}$ as intercept.

It can be observed from Fig. 5 and 6 that both Freundlich and Langmuir isotherms model exhibited good fit to the sorption data of $\mathrm{Pb}$ (II). From show in Table 2, it is concluded that the Fruendlich isotherm model is slight better than Langmuir isotherm model to fit $\mathrm{Pb}$ (II) sorption data well cover a concentration range 25-200 $\mathrm{mg} \mathrm{L}^{-1}$. Figure 5, shows the linear plot of $\ln \mathrm{q}_{\mathrm{e}}$ versus $\operatorname{lnC}_{\mathrm{e}}$ giving a straight line $\left(\mathrm{r}^{2}=0.9871\right)$ and Fig. 6, shows the linear plot of $1 / \mathrm{q}_{\mathrm{e}}$ versus $1 / \mathrm{C}_{\mathrm{e}}$ giving a straight line $\left(r^{2}=0.9724\right)$, with slope $1 / n$ and intercept lnk and the characteristic parameters $\mathrm{q}_{\max }$ and b for Freundlich and Langmuir isotherm respectively. The values of the Langmuir and Freundlich constants are presented in show in Table 2, for the agarose gel adsorption system.

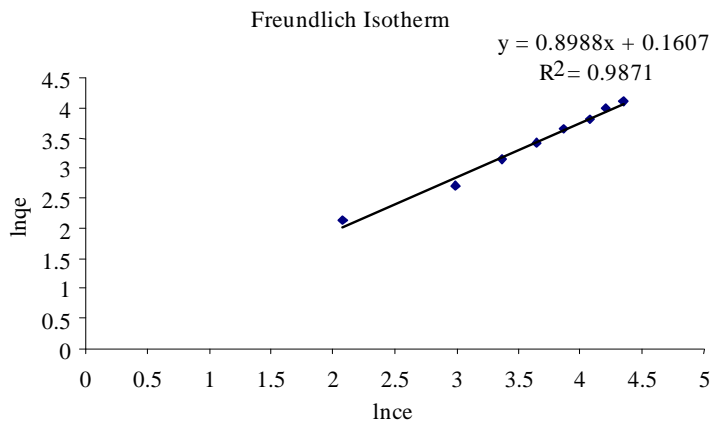

Fig. 5: Freundlich adsorption isotherms for $\mathrm{Pb}$ (II) biosorption by agarose gel, metal ion concentration range $25-200 \mathrm{mg} \mathrm{L}^{-1}$, contact time $4 \mathrm{~h}$ at $\mathrm{pH} 2.0$ and temperature $35^{\circ} \mathrm{C}$

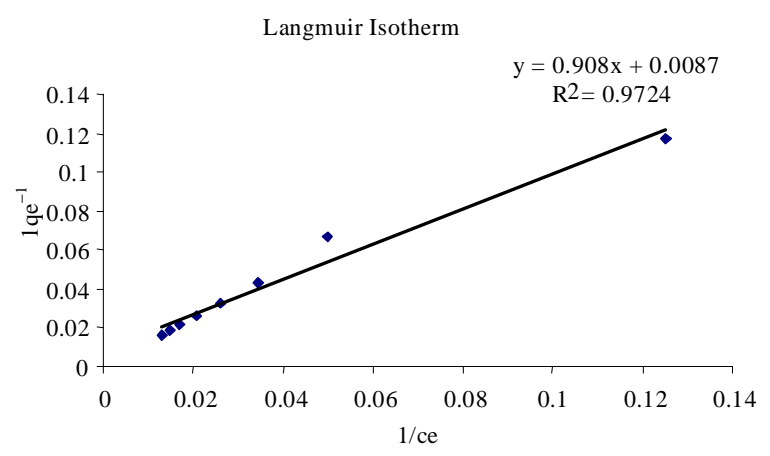

Fig. 6: Langmuir adsorption isotherms for $\mathrm{Pb}(\mathrm{II})$ biosorption by agarose gel, metal ion

\begin{tabular}{|c|c|c|c|c|c|}
\hline \multicolumn{3}{|c|}{ Langmuir isotherm } & \multicolumn{3}{|c|}{ Freundlich isotherm } \\
\hline $\mathrm{q}_{\max }\left(\mathrm{mg} \mathrm{g}^{-1}\right)$ & $\mathrm{b}\left(\mathrm{L} \mathrm{mg}^{-1}\right) \mathrm{r}^{2}$ & & $\mathrm{~K}_{\mathrm{F}}$ & $\mathrm{n}$ & $r^{2}$ \\
\hline 115 & 0.0095 & 0.9724 & 1.1 & 1.1 & 0.9871 \\
\hline
\end{tabular}
concentration range $25-200 \mathrm{mg} \mathrm{L}^{-1}$, contact time $4 \mathrm{~h}$ at $\mathrm{pH} 2.0$ and temperature $35^{\circ} \mathrm{C}$

Table 2: Langmuir and Freundlich isotherm constants

Desorption studies: Efficient removal of loaded metal from the agarose gel was necessary to ensure their longterm use for repeated extraction-elution cycles. The regeneration of the biosorbent is likely to be a key factor in accessing the potential of the biosorbent for commercial application $^{[15]}$. The capacity of the agarose gel to adsorb metal ions and the degree of mechanical stability of gel was determined by repeating the adsorption-desorption experiments in three consecutive cycles. $0.1 \mathrm{M}$ EDTA, $0.1 \mathrm{~N} \mathrm{NaOH}$ and $0.1 \mathrm{~N} \mathrm{H}_{2} \mathrm{SO}_{4}$ solutions was used as desorbing agent. 0.1 M EDTA was found to be effective elutant than $0.1 \mathrm{~N} \mathrm{H}_{2} \mathrm{SO}_{4}$ and $0.1 \mathrm{~N} \mathrm{NaOH} \mathrm{Fig.} \mathrm{7,} \mathrm{which} \mathrm{shows} \mathrm{that} \mathrm{agarose} \mathrm{has}$ 
Am. J. Biochem. \& Biotech., 5 (1): 14-20, 2009

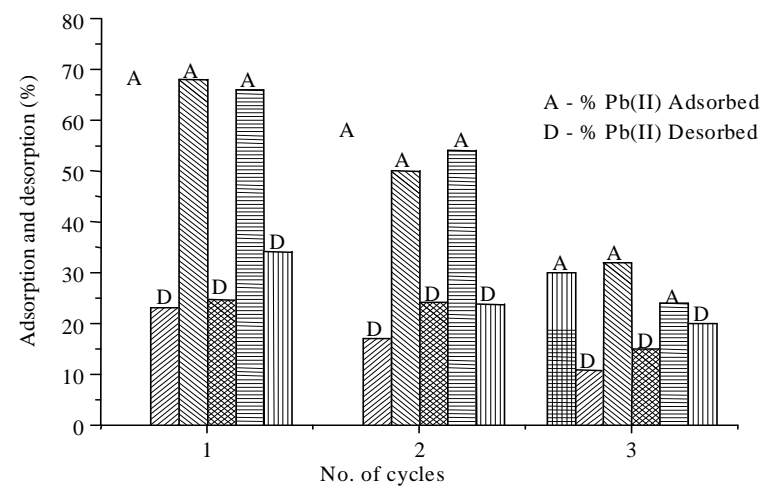

Fig. 7: Percentage $\mathrm{Pb}$ (II) uptake and recovery in successive cycles using elutant as $0.1 \mathrm{~N} \mathrm{H}_{2} \mathrm{SO}_{4}$, $0.1 \mathrm{~N} \mathrm{NaOH}$ and $0.1 \mathrm{M}$ EDTA, adsorption period $=4 \mathrm{~h}$, metal ion concentration $=25$ $\mathrm{mgL}^{1}$, adsorption $\mathrm{pH}=2.0$, volume of elutant $=$ $20 \mathrm{~mL}$, desorption period $=60 \mathrm{~min}$, biosorbent dose $=1 \%$

potential to adsorb and desorb $\mathrm{Pb}$ (II) ions repeatedly from aqueous solution.

\section{CONCLUSION}

Agarose gel was capable of removing $\mathrm{Pb}$ (II) from solution efficiently. Pseudo second-order was applicable to all sorption data over entire time range. Kinetics of $\mathrm{Pb}(\mathrm{II})$ ions on biosorption on agarose gel was found to be dependent on experimental conditions, particularly the medium $\mathrm{pH}$, temperature and the initial concentration of metal ions. The Freundlich and Langmuir adsorption models was used to represent the experimental data and equilibrium data fitted very well to both the Freundlich and Langmuir isotherm model. The Freundlich isotherm represented the equilibrium data slightly better than Langmuir isotherm well cover a concentration range 25-200 $\mathrm{mg} \mathrm{L}^{-1}$. The adsorbed metal ion was effectively eluted to be in the order of $0.1 \mathrm{M}$ EDTA $>0.1 \mathrm{~N} \mathrm{NaOH}>0.1 \mathrm{~N} \mathrm{H}_{2} \mathrm{SO}_{4}$ solution and was reused in three adsorption-desorption cycles. These studies show that agarose gel has the potential to be used as biofilter for removal and recovery of $\mathrm{Pb}$ (II) from contaminated water, which is environmentally friendly.

\section{REFERENCES}

1. Banerjee, M. and S. Mishra, 2002. Mitigating effect of immobilization on Aulosira fertilissima subjected to nickel and chromium stress. Bull. Biosci., 1: 43-46.
2. ATSDR. 1992. Case studies in environmental medicine: Lead toxicity, US Department of Health and Human Services, Public Health Service, Agency for Toxic Substances and Disease Registry, Atlanta, GA.

http://wonder.cdc.gov/wonder/prevguid/p0000017/ p0000017.asp

3. Brierley, J.A. and C.L. Brierley, 1986. G.M. AMTBioclaim: A New Wastewater Treatment And Metal Recovery Technology. In: Fundamental and Applied Biohydrometallurgy, Lawrence et al., (Ed.). Elsevier, Amsterdam, pp: 291-303.

4. Wilde, E.W. and J.R. Benemann, 1993. Bioremoval of heavy metals by the use of microalgae. Biotechnol. Adv., 11: 781-812. http://www.ncbi.nlm.nih.gov/pubmed/14538057

5. Bolton, H. and Y.A. Gorby, 1995. An overview of the bioremediation of metal-contaminated industrial effluents using waste sludges. Water Sci. Technol., 34: 9-15.

6. Pagnanelli, F., M.P. Petrangeli, L. Toro, M. Trifoni and F. Veglio, 2000. Biosorption of metal ions on Arthrobacter sp: Biomass characterization and biosorption modeling. Environ. Sci. Technol., 34: 2773-2778.

http://cat.inist.fr/?aModele=afficheN\&cpsidt=1477484

7. Fourest, E. and J.C. Roux, 1992. Heavy metal biosorption by fungal mycelial by products: Mechanism and influence of $\mathrm{pH}$. Applied Microbiol. Biotechnol., 37: 399-403. http://cat.inist.fr/?aModele=afficheN\&cpsidt=5607231

8. Gadd, G.M., 1990. Fungi and Yeasts for Metal Accumulation. In: Microbial Mineral Recovery, Ehrlich et al., (Ed.). McGraw Hill, New York, pp: 249-276.

9. Bai, S.R. and T.E. Abraham, 2001. Biosorption of $\mathrm{Cr}$ (VI) from aqueous solution by Rhizopus nigricans. Bioresour. Technol., 79: 73-81. DOI: 10.1016/S0960-8524(00)00107-3

10. Deans, J.R. and B.G. Dixon, 1992. Uptake of Pb2+ and $\mathrm{Cu} 2+$ by novel biopolymers. Water Res., 26: 469-472.

http://cat.inist.fr/?aModele=afficheN\&cpsidt=5197564

11. Butter, T.J., L.M. Evison, I.C. Hancock, F.S. Holland, K.A. Matis, A. Philipson, A.I. Sheikh and A.I. Zouboulis, 1998. The removal and recovery of cadmium from dilute aqueous solutions by biosorption and electrolysis at laboratory scale. Water Res., 32: 400-406. http://cat.inist.fr/?aModele=afficheN\&cpsidt=2187087 
12. Brady, D., A. Stoll and J.R. Duncan. 1994. Biosorption of heavy metal cations by non-viable yeast biomass. Environ. Technol., 17: 791-796.

13. Ho, Y.S. and G. McKay, 1999. Pseudo-second order model for sorption processes. Process Biochem., 34: 451-465.

http://direct.bl.uk/bld/PlaceOrder.do?UIN=085527 $368 \&$ ETOC $=$ RN\& from=searchengine

14. Spiniti, M., H. Zhuang and E.M. Trujillo, 1995. Evaluation of immobilized biomass beads for removing heavy metals from wastewater. Water Environ. Res., 67: 943-952.

http://cat.inist.fr/?aModele=afficheN\&cpsidt=3669629
15. Iqbal, M. and R.G.J. Edyvean, 2004. Biosorption of lead, copper and zinc on loofa sponge immobilized biomass of Phanerochaete chrysosporium. Minerals Eng., 17: 217-223. http://cat.inist.fr/?aModele $=$ afficheN\&cpsidt $=15486170$ 